\title{
Performance and Blood Profile of Grass Cutters (Thryonomys swinderianus) Fed Wild Sunflower (Tithonia diversifolia Hamsl. A Gray) Leaf Meal
}

\author{
J. O. Alagbe \\ Department of Animal Production and Health, Ladoke Akintola University of Technology, Ogbomosho, Oyo state, P.M.B 4000, \\ Ogbomosho
}

\begin{abstract}
A 60 day trial involving forty, 3-months old weaned grass cutters of mixed breeds and sex with initial weight of between 830 and $850 \mathrm{~g}$ was conducted to examine the effect of feeding different levels of wild sunflower leaf meal on the performance and blood profile of weaner grass cutter. The grass cutters were randomly assigned into five treatment diets in a Completely Randomized Design [CRD] and each group was further sub-divided into three replicates containing three grass cutters each. The grass cutters were fed with formulated growers diet supplemented with Sunflower meal at levels of 0\%, 5\%, 10\%, 15\% and 20\% representing treatments 1, 2, 3, 4 and 5 respectively. Feed intake, final weight gain were the performance criteria measured while the blood profile includes hematology and serum analysis. Results showed that the grass cutters fed Wild sunflower meal were not significantly $(P>0.05)$ in terms of their feed intake, final live weight and hematology. SGPT and SGOT were the only parameters that were significantly affected $(P<0.05)$ with the inclusion of Wild sunflower meal during the serum biochemical analysis. The result of the experiment demonstrated that the inclusion of Wild sunflower at $20 \%$ does not have a deleterious effect on growth, performance and health status of grass cutters.
\end{abstract}

Keywords: grass cutter, wild sunflower meal, performance, growth, health status

\section{Introduction}

In a world where malnutrition and starvation stare the entire human race on the face, it is amazing to note that there exists much wastage of agro-industrial by products which could be utilized for increased food production especially the animal protein foods. In cases where such by-products are utilized, they are inappropriately or grossly underutilized.

Protein plays a significant role in the diet of animals. Recently, the cost of conventional sources of protein had been on a continuous increase and in most times they are not available. The situation keeps getting complex especially in less developed countries as a result of competition between human and livestock population. It is therefore important to explore the use of non conventional feedstuff that have the capacity to yield the same output as conventional feeds and perhaps at a cheaper cost. For instance, leaf meals from tropical legumes are good source of cheap protein that can be fed to animals to obtain good result.

Grass cutters also known as cane-rat are wild hystricomorphic rodents found only in Africa (Adoun, 1993). They have the ability to utilize cellulose or fibre fraction in feed (NRC, 1991; Asibey and Addo, 1970).

Grass cutters are strictly herbivores, and prefer mainly thick stemmed grass species (Schrage and Yewadan, 2000). According to Annor et al.( 2009), he reported that grass cutter meat is of higher nutritional value and meat yield.

Adu et al. (2003), found the nutritional qualities of bush meat to be comparable to those of conventional meats. The protein is of high biological values containing all essential amino -acids such as methionine, lysine, leucine, isoleucine, valine etc. (Omole et al, 2005). The meat compares favorably with pork, beef, and poultry meat and so on which are conventional sources of animal protein.

According to Annor. et al, (2006). Wild sunflower as one of the leaf meals is a weed of crops, waste land and roadsides. A lot of research has been carried out to determine the feeding values and chemical composition of wild sunflower leaf in poultry diets (Odunsi et al, 1999) and other ruminant animals (Asibey. et al,2004). However, there is a dearth of information on the effect of wild sunflower meal on grass cutter's performance when included in their feed.

This study was designed to investigate the effect of feeding wild sunflower meal on the performance and blood profile of weaned grass cutter.

\section{Materials and Methods}

Location of experiment

The experiment was carried out at the Teaching and Research Farm of Ladoke Akintola University of Technology (LAUTECH), Ogbomosho, Nigeria. The area is located within the derived savannah zone of Nigeria.

\section{Animals and their management}

Forty-five, 3 months old weaned male grass cutters with an average weight of 830 and 850 grams were randomly assigned to five dietary treatment of nine grass cutter per group in a completely randomized experimental design. The grass cutters were housed in a concrete cell measuring $200 \times 80 \times 40 \mathrm{~cm}$ (length $\times$ breath height) which was disinfected one month before the arrival of the animals. The floor of the cell was made of solid concrete, temperature within the cells were within the range of $27-30^{\circ} \mathrm{C}$ during the period of experiment. On introduction of the grass cutter the anti stress (strexia) was added into the drinking water. Feed intake and weights were recorded daily and weekly 


\section{International Journal of Science and Research (IJSR) \\ ISSN (Online): 2319-7064 \\ Index Copernicus Value (2013): 6.14 | Impact Factor (2015): 6.391}

respectively throughout the experiment, which lasted for 60 days.

\section{Preparation of experimental diets}

Wild sunflower leaf meal was prepared by air drying wild sunflower strands harvested when the first inflorescence had opened in $50-80 \%$ of the plants; it is later spread on a concrete floor to air dry. The dried leaves from the strands are removed and grinded with a hammer mill and stored in a container. The processed Wild sunflower meal was later subjected to proximate analysis as expressed in Table 1.

The test ingredient (WSFLM) was mixed with other ingredients to form five (5) experimental diets at levels of 0 , $5,10,15$ and $20 \%$. The proximate composition is presented in Table 2.

\section{Blood Analysis}

At the end of 60 days of the experiment, blood samples were collected from five randomly selected grass cutters per treatment. The blood samples meant for haematology was collected into an Ethylene Diamine Tetra acetic Acid (EDTA) bottle while the sample for serum were collected into another bottle free from anticoagulant (EDTA). The haematological indices determined included Haematocrit, Haemoglobin concentration $(\mathrm{Hb})$, Red blood cell count (RBC), White blood cell count (WBC), Mean corpuscular volume (MCV), Mean corpuscular haemoglobin concentration (MCHC), Mean corpuscular haemoglobin $(\mathrm{MCH})$ and white blood differential counts which includes Lymphocyte, Monocytes and Neutrophils. The haemoglobin concentration was determined by colometry-

cyanomethacmoglobin method, Red blood cell counts were determined by Neubauer haemocytometer method, Pack cell volume was determined by the micro-haematocrit method (Dacie and Lewis, 1991).

The blood samples that were meant for serum chemistry were collected into other bottles free from any anticoagulant. The parameters determined include: Albumin and Globulin which were calorimetrically determined using diagnostic reagent kits. Activities of Serum glutamic oxaloacetate transaminase (SGOT), Serum glutamic oxaloacetate transaminase(SGPT) and Alkaline phosphatase (ALP) were determined colorimetrically ( Reitman and Frankel, 1957).

The proximate component of the Wild sunflower meal (WSFLM) and the samples of the five experimental diets were determined by method of A.O.A.C (1990). All data collected were subjected to one way analysis of variance and significant means separated by Duncan multiple range tests. (Duncan, 1955).

Table 1: Proximate Composition of Wild Sunflower Leaf Meal.

\begin{tabular}{|l|r|}
\hline Nutrients & \% DM \\
\hline Crude Protein & 20.23 \\
Crude Fibre & 10.34 \\
Ether extracts & 7.01 \\
Ash & 15.01 \\
Nitrogen Free Extract & 46.21 \\
\hline
\end{tabular}

Table 2:Percentage Composition of the Experimental Diets

\begin{tabular}{|lccccc|}
\hline Ingredients & \multicolumn{5}{c|}{ Diets } \\
\hline Maize & 1 & 2 & 3 & 4 & 5 \\
Wheat offal & 48.0 & 48.0 & 48.0 & 48.0 & 48.0 \\
Soya Meal & 36.25 & 36.25 & 36.25 & 36.25 & 36.25 \\
Groundnut Cake & 12.0 & 12.0 & 12.0 & 12.0 & 12.0 \\
Bone meal & 1.0 & 1.0 & 1.0 & 1.0 & 1.0 \\
Oyster shell & 1.5 & 1.5 & 1.5 & 1.5 & 1.5 \\
G/Premix & 0.5 & 0.5 & 0.5 & 0.5 & 0.5 \\
Salt & 0.25 & 0.25 & 0.25 & 0.25 & 0.25 \\
WSFLM & 0.50 & 0.50 & 0.50 & 0.50 & 0.50 \\
& 0 & 05 & 10 & 15 & 20 \\
\hline Determined Analysis & 100 & 100 & 100 & 100 & 100 \\
Crude Protein & 14.80 & 15.10 & 15.03 & 15.08 & 15.13 \\
Crude Fibre & 6.0 & 6.0 & 6.0 & 6.0 & 6.0 \\
Ether extract & 3.74 & 3.74 & 3.74 & 3.74 & 3.74 \\
Ash & 3.6 & 3.6 & 3.6 & 3.6 & 3.6 \\
NFE & 61.2 & 61.2 & 61.2 & 61.2 & 61.2 \\
Metabolizable energy & 2632 & 2621 & 2614 & 2609 & 2601 \\
\hline
\end{tabular}

*Vitamin -mineral premix contained: Vit A ,1500 IU; Vit D3, 2500 IU; Vit E, 11 IU; Vit B2, 10mg; Vit B3, 40mg; Vit B6, 20mg; Choline chloride, 400mg; Manganese, 120mg; Iron, 70mg; Copper, 10mg; Iodine, 2.2mg; Selenium, 0.2mg; Zinc, 45mg; Cobalt,0.02mg.

Volume 5 Issue 6, June 2016 www.ijsr.net 


\section{International Journal of Science and Research (IJSR) \\ ISSN (Online): 2319-7064}

Index Copernicus Value (2013): 6.14 | Impact Factor (2015): 6.391

Table 3: Performance and Hematological traits of Grass cutter fed varying levels of WSFML

\begin{tabular}{|l|c|c|c|c|c|c|}
\hline \multicolumn{7}{|c|}{ Diets } \\
\hline Parameters & 1 & 2 & 3 & 4 & 5 & S/L \\
\hline Initial Live weight (g) & $855 \pm 39.1$ & $856 \pm 45.4$ & $860 \pm 48.4$ & $850 \pm 53.1$ & $854 \pm 36.6$ & NS \\
Final Live weight (g) & $1330 \pm 31.9$ & $1296.1 \pm 55.2$ & $1288 \pm 46.1$ & $1298 \pm 43.2$ & $1298.7 \pm 33.1$ & NS \\
Avg. Feed intake (g/day) & $1360 \pm 22.5$ & $1357 \pm 30.1$ & $1389 \pm 41.0$ & $1375 \pm 23.9$ & $1398 \pm 46.1$ & NS \\
Haematocrit (\%) & $23.0 \pm 2.34$ & $25.6 \pm 3.50$ & $29.6 \pm 2.70$ & $32.4 \pm 1.56$ & $35.1 \pm 4.35$ & NS \\
Red blood cells & $2.89 \pm 0.65$ & $3.34 \pm 0.31$ & $5.02 \pm 0.78$ & $6.73 \pm 0.07$ & $6.12 \pm 0.24$ & NS \\
Hemoglobin(g/dl) & $8.06 \pm 1.35$ & $8.49 \pm 0.72$ & $10.3 \pm 1.26$ & $9.08 \pm 0.44$ & $9.03 \pm 0.55$ & NS \\
MCV (fl) & $46.5 \pm 0.34$ & $45.9 \pm 0.78$ & $47.9 \pm 1.70$ & $47.7 \pm 0.45$ & $47.1 \pm 0.22$ & NS \\
MCH(Pg) & $16.1 \pm 0.21$ & $16.3 \pm 0.08$ & $16.8 \pm 0.43$ & $16.2 \pm 0.51$ & $16.7 \pm 0.14$ & NS \\
MCHC (g/d) & $29.8 \pm 0.15$ & $30.3 \pm 0.23$ & $30.1 \pm 1.20$ & $31.1 \pm 0.65$ & $30.4 \pm 1.34$ & NS \\
WBC (mm3) & $3.50 \pm 0.67$ & $3.03 \pm 0.21$ & $6.89 \pm 0.77$ & $7.59 \pm 0.34$ & $7.99 \pm 0.15$ & NS \\
Neutrophils (\%) & $24.5 \pm 1.78$ & $23.7 \pm 1.20$ & $24.08 \pm 1.65$ & $23.07 \pm 1.23$ & $24.5 \pm 1.20$ & NS \\
Lymphocytes (\%) & $47.0 \pm 1.40$ & $46.9 \pm 0.09$ & $48.0 \pm 0.21$ & $48.6 \pm 0.31$ & $49.6 \pm 0.78$ & NS \\
Monocytes (\%) & $1.28 \pm 0.31$ & $1.32 \pm 0.48$ & $1.37 \pm 0.12$ & $1.39 \pm 0.61$ & $1.47 \pm 0.70$ & NS \\
\hline
\end{tabular}

$\mathrm{NS}=$ No significant difference $(\mathrm{P}>0.05)$

$\mathrm{MCV}=$ Mean corpuscular haemoglobin

$\mathrm{MCH}=$ Mean corpuscular haemoglobin

$\mathrm{MCHC}=$ Mean corpuscular haemoglobin concentration

$\mathrm{WBC}=$ White blood cell

Table 4: Serum biochemical Parameters of Grass cutters Fed varying levels of WSFLM

\begin{tabular}{|lcccccc|}
\hline \multicolumn{7}{c|}{ Diets } \\
\hline Parameters & 1 & 2 & 3 & 4 & 5 & $\mathrm{~S} / \mathrm{L}$ \\
\hline Albumin $(\mathrm{g} / \mathrm{dl})$ & $2.10 \pm 0.06$ & $2.20 \pm 0.13$ & $2.34 \pm 0.10$ & $2.39 \pm 1.20$ & $2.51 \pm 0.09$ & $\mathrm{NS}$ \\
Globulin (g/d) & $2.34 \pm 0.03$ & $2.56 \pm 0.09$ & $2.76 \pm 0.02$ & $2.61 \pm 0.08$ & $2.67 \pm 0.06$ & NS \\
Total Protein (g/dl) & $4.15 \pm 0.15$ & $4.70 \pm 0.13$ & $5.10 \pm 0.10$ & $5.12 \pm 0.17$ & $5.25 \pm 0.09$ & NS \\
SGPT (U/L) & $5.40 \pm 0.45$ & $6.33 \pm 0.33$ & $8.11 \pm 0.45$ & $11.2 \pm 0.75$ & $14.3 \pm 0.56$ & $*$ \\
SGOT (U/L) & $11.3 \pm 0.98$ & $12.4 \pm 1.54$ & $13.9 \pm 1.56$ & $15.7 \pm 1.23$ & $18.1 \pm 1.45$ & $*$ \\
ALP (U/L) & $30.6 \pm 1.23$ & $30.8 \pm 0.21$ & $31.8 \pm 1.76$ & $32.0 \pm 1.52$ & $31.7 \pm 1.12$ & NS \\
\hline
\end{tabular}

$\mathrm{NS}=$ No significant difference $(\mathrm{P}>0.05)$

$*=$ Significant different $(\mathrm{P}<0.05)$

SGPT $=$ Serum Glutamic Pyruvate Transaminase

SGOT $=$ Serum Glutamic Oxaloacetate Transaminase

ALP $=$ Alkaline Phosphatase

\section{Result}

Table 1 shows the proximate composition of Wild sunflower meal. The proximate components shows that values for crude protein, crude fibre, ether extract and ash are $20.23 \%$, $10.34 \%, 7.01 \%$ and $15.01 \%$ respectively.

The Percentage composition of experimental diets is indicated in Table 2.

Table 3 shows the growth and the values of the various hematological traits of grass cutters fed Wild sunflower meal. The grass cutter final live weight ranges between $1288 \mathrm{~g}$ and $1330 \mathrm{~g}$. There is no significant difference $(\mathrm{P}<0.05)$ among the treatment in term of their final live weight.

The values obtained for haematocrit (\%) are 23.0, 25.6, 29.6, 32.4 , and 35.1 for diets $1,2,3,4$ and 5 respectively while those for the heamoglobin $(\mathrm{g} / \mathrm{dl})$ are 8.06, 8.49, 10.3, 9.08 and 9.03 for diets $1,2,3,4$ and 5 respectively. The values obtained for Red blood cell $(\times 106 \mathrm{~mm} 3)$ are 2.89, 3.34, 5.02, 6.73 and 6.12 for diets $1,2,3,4$ and 5 respectively.
The values for the Mean corpuscular volume (fl) are 46.5, $45.9,47.9,47.7$, and 47.1 for diet 1,2,3,4 and 5 .

The values of the White blood cell (WBC) were not significantly affected by the dietary inclusion of Wild sunflower meal $(\mathrm{P}>0.05)$ as the values marginally increased from diet 1 to 5 .

Heamoglobin (Hb), Haematocrit (Ht), Red blood cells (RBC), Mean corpuscular volume (MCV), Mean corpuscular haemoglobin concentration $(\mathrm{MCHC})$ were not significantly affected $(\mathrm{P}>0.05)$ with the dietary inclusion of Wild sunflower meal, their values gradually increased from diet 1 to 5 .

The serum analysis the values obtained for Albumin $(\mathrm{g} / \mathrm{dl})$ were $2.10,2.20,2.34,2.39$ and 2.51 for diets $1,2,3,4$ and 5 respectively. While those for globulin are 2.34, 2.56, 2.76, 2.61 and 2.67 for diets $1,2,3,4$ and 5 . The values for the total protein are $4.15,4.70,5.10,5.12$ and 5.25 for diets $1,2,3,4$ and 5 respectively. Albumin, globulin, total proteins were not significantly $(\mathrm{P}>0.05)$ affected with the inclusion of Wild sunflower meal in the diet.

\section{Volume 5 Issue 6, June 2016 www.ijsr.net}




\section{International Journal of Science and Research (IJSR) \\ ISSN (Online): 2319-7064}

Index Copernicus Value (2013): 6.14 | Impact Factor (2015): 6.391

Alkaline phosphatase (ALP) values were marginally increased from diet 1 to 4 after which the values declined, but there was no significant difference in its values $(\mathrm{P}>0.05)$.

Serum glutamic pyruvate transaminase and Serum glutamic oxaloacetate transaminase values were significantly affected $(\mathrm{P}<0.05)$ with inclusion of Wild sunflower meal in their diets, there was a significant rise in the values from diet 1 to 5 .

\section{Discussion}

The inclusion of Wild sunflower meal in the experimental diet increased the crude protein level in the diet but has no significant effect on the $(\mathrm{P}>0.05)$ final weight of the grass cutters in the entire treatment group.

The values of the Haematocrit (Ht), Haemoglobin (Hb), Red blood cell (RBC), Mean corpuscular volume (MCV), Mean corpuscular haemoglobin concentration (MCHC), White blood cell (WBC) and Mean corpuscular haemoglobin $(\mathrm{MCH})$ were not significantly affected $(\mathrm{P}>0.05)$, the heamatocrit and the red blood cell value is a clear indication that the inclusion of wild sunflower meal did not alter the transportation of nutrients and oxygen circulation in the body of the animal. According to Johnson et al. (2006), RBC serves as a carrier of haemoglobin. Isaac et al. (2013) also reported that RBC is involved in the transport of oxygen and carbon dioxide in the body while Heamatocrit $(\mathrm{Ht})$ is involved in the transport of oxygen and absorbed nutrients.

The WBC values increased with the inclusion of Wild sunflower meal in the experimental diet, this is an indication that antibodies production to fight any foreign organisms which may try to gain entrance into the body of the grass cutter. Iwuji and Herbert, 2012 reported that generating antibodies in the body enhances adaptability to local environment.

The values for the haematological parameters all fall within the range reported by Byanet, et al (2008). Anti-nutrients such as (alkaloid, flavonoid, tannin and phytin) present in Wild sunflower as reported by Fasuyi et al. (2010) did not affect the above mentioned blood parameters but this was contrary to a report by Gaus and Dupreez (1975) when sun flower meal was included in the feed of birds.

The Serum biochemical parameters reveals that the values of albumin, globulin and total protein were not significantly affected $(\mathrm{P}>0.05)$ by the inclusion of Wild sunflower meal in the diets, this shows that there are available protein in the feed which are easily released into the animal's body for body maintenance and functioning, this agrees with the findings of Olabanji et al. (2007) in rabbits. The range for all these parameters fall within the normal range established for grass cutter by Byanet et al. (2008).

According to Guache et al. (1991) albumin values after an analysis can be influenced or affected by protein shortages. However, the values for SGPT and SGOT were significantly affected $(\mathrm{P}<0.05)$ with the inclusion of Sunflower meal in the diet, the values gradually increased from diet 1-5, According to Iyayi (1994), SGPT and SGOT usually respond to the presence of toxic substance in the feed. This agrees with the findings of Olabanji et al. (2007) on feeding rabbits with Wild sunflower blood meal mixture in rabbits.

\section{Conclusion}

Most of the parameters tested viz growth performance, hematological and biochemical indices showed no significant differences. It can therefore be concluded that the inclusion of Wild sunflower meal up to $20 \%$ have no deleterious effect on performance and blood profile of weaner grass cutters.

\section{References}

[1] AOAC (2000) Association of Official Analytical Chemist, Official Method of Analysis $17^{\text {th }}$ edition Washington D.C.

[2] Annor et al. (2009) Grass cutter Production: A Handbook Qualitype Ltd. Accara, Ghana. 109pp

[3] Annor et al. (2011). The genetics of docility of the Grass cutter Livestock Research for Rural Development.

[4] Adu, E.K and P.A Wallace (2003) Growth and Reproductive Performance of Grass cutters Fed Fresh cut Panicum maximum J. Ghana Science Association 5:90-93.

[5] Asibey, E.O.A (1970) The present status of wildlife in Ghana. IUCN Publication No. 22:15-21

[6] Asibey, E.O.A (1974) Reproduction in the Grasscutter( Thrynomys swinderianus, Temminck) in Ghana. Symp. Zool. Soc. London. 34, 251-263

[7] Byanet et al. (2008) Haematological and Plasma Biochemical Parameters of Young Grass cutter (Thyronomys swinderianus) reared in Northern Nigeria. Journal of Cell and Animal Biology. Vol (10) PP. 177181.

[8] Duncan I.R (1955). Multiple Range and Multiple F-Test Biometrics 11:1-42

[9] Doumas, B.T and Briggs, H.G (1972) Serum Albumin Bromocresol Green Binding Standard Methods. Clinical Chemistry (7) 175-179.

[10] Fasuyi et al. (2010) Ensiling Wild sunflower (Tithonia diversifolia) Leaves with Sugarcane molasses. Livestock Research for Rural Development. 22(3) 2010.

[11]Farinu, G.O (1996) Agronomic and Nutritive Evaluation of Wild sunflower( Tithonia diversifolia . Hemsel A. Gray) Comprehensive Project Implementation Brief, pp1-6.

[12] Gaus, R.M and Dupreez (1975). The Sequential feeding of Growing chickens. Bri. J. Nutr. 34:113-118

[13] Iyayi , E.A (2001) Cassava Leaves as Supplement for Feeding weaner swine. Trop. Anim. Prod. Invest. 4:141150.

[14] Isaac et al. (2013) Haematological properties of different breeds and sexes of rabbits (p.24-27). Proceedings of the $18^{\text {th }}$ Annual Conference of Animal Science Association of Nigeria.

[15] Iwuji, T.C., \& Herbert, U (2012). Heamatological and Serum biochemical characteristics of rabbit bucks fed diets containing garcimiola kola seed meal. (p.87-89). Proceedings of $37^{\text {th }}$ Annual Conference of Nigeria Society of Animal Production.

\section{Volume 5 Issue 6, June 2016 www.ijsr.net}




\section{International Journal of Science and Research (IJSR) \\ ISSN (Online): 2319-7064}

Index Copernicus Value (2013): 6.14 | Impact Factor (2015): 6.391

[16] Iheukwumwere, F.C., \& Herbert, U (2002). Physiological Responses of Broiler Chickens to Quantitative Water Restrictions. Haematology and Serum Biochemistry. International Journal of Poultry Science, 2(2), 117-119.

[17] Johnson, J.K., \& Morris, D.D. (1996) Alterations in Blood proteins. In B.P. Smith (Ed). International Animal Medicine ( $2^{\text {nd }}$ ed). USA: Mosby Publishers.

[18] Mitruka, B.M., \& Rawnsley, H.M (1977). Clinical biochemical and heamatologcal reference values in normal experimental animals (p. 134-135). USA: Masson Publishing Inc.

[19] Odunsi et al. (1999). Growth carcass characteristics and body composition of broiler chickens fed wild sunflower forage meal. Trop. Anim. Prod Invest. 2:205211

[20] Odunsi et al. (1997). Assesment of Nigerian mango (Magnifera indica) seed kernel as a partial replacement for maize in finishing broiler diets. Indian. J.Animal Science ., 67:605-607

[21] Omole et al. (2011). Small and medium scale grasscutter (Back to Agric. Series 11), Published by Green choice Agric. Publication (p. 2-7).

[22] Research Animal Resource [RAR]. (2009). Reference values for laboratory animals: Normal haematological values. RAR Websites, RAR, University of Minnesota. Retrieved from http://www.ahc.umn.edu/rar/refvalues.html.

[23] Schalm, O.W., Jain, N.C., \& Carroll, E.J. (1975). Veterinary haematology ( $3^{\text {rd }}$ ed., p.15-2180. USA:Lea \& fabiger, Philadelpia.

[24] Ugwuene, M.C (2011). Effects of Dietary Palm Kernel Meal on the Haematology and Serum Chemistry of Broiler Turkey. Nigerian Journal of Animal Science 13,93-103.

[25] Van et al. (1987). Genetics for Animal Sciences. W.H. Freeman \& Co., 391pp.

[26] Yewadan, T.L (2000). Schẻma de sẻlection en ẻlevage d'aulacodes ( Thryonomys swinderianus). Acquis, Perspectives, intẻréets de multiplication et des collaborations a ce niveau In: Actes Sếminaire International sur l'êlevage intensif gibier a but alimentaire a Libreville (Gabon), Projet DGEG/VSF/ADIE/CARPE/UE. 